\title{
The Decline of the Angora Goat Industry in Three Texas Counties
}

\author{
JERRY H. SCRIVNER
}

\begin{abstract}
One hundred three present and 104 past Angora goat producers in 3 Texas counties were questioned regarding the relative importance of factors contributing to the decline of the goat industry in Texas. While the distribution of past and present producers among herd-size, ownership, and age classes was similar, it differed with regard to kidding. More present producers attempted to reduce livestock losses by shed and shed/trap kidding and use of predator control and husbandry techniques. Present producers also reported fewer kids and adults killed by predators. Predation losses was the production-limitation factor of greatest concern to both present and past goat ranchers. Disease problems and concern over competition from the synthetic fiber industry were ranked second and third, respectively, by present producers whereas mohair prices were ranked second and shortage of shearers, disease problems, and competition from the synthetic fiber industry collectively were ranked third by past producers.
\end{abstract}

The Angora goat industry is an important part of the agricultural economy of Texas. Texas has more than $90 \%$ of the Angora goats in the United States with an estimated population of 1.1 million in 1983 (Texas Crop and Livestock Reporting Service 1983a). Goat numbers in Texas have been cyclic for nearly 60 years; however, during the past 18 years, the number of goats shorn has declined $72 \%$. In 1965, at the peak of the goat industry, 4.6 million goats produced 14.3 million $\mathrm{kg}$ of mohair valued at $\$ 20.8$ million (Texas Crop and Livestock Reporting Service 1981a), whereas in 1982,1.3 million goats produced 4.4 million $\mathrm{kg}$ valued at $\$ 25.0$ million (Texas Crop and Livestock Reporting Service 1983a).

Published data regarding the cause of this decline are lacking. Bowns (1980) suggested that low mohair prices in the mid-1960's and early 1970's were the major reason Angora goat numbers decreased, but predator problems were a strong second factor. Kensing $(1978,1980)$ suggested that flock liquidations have resulted primarily from economic losses due to predation.

Data are more complete regarding factors influencing the decline of the sheep industry. Generally, U.S. sheep numbers have steadily declined from a high of 57 million animals in 1942 (Cothern 1981) to 11.9 million in 1983 (Banks 1983), a 79\% decline. Gee et al. (1977) suggested that the decrease in sheep numbers has resulted from farmers and ranchers either discontinuing sheep enterprises or reducing herd sizes, with ewes being slaughtered rather than retained for stocking purposes. Gee et al. (1977) and others (Early et al. 1974a, b, Neese et al. 1976, Stevens and Hartley 1976) suggested that the reasons for these actions by produccrs include excessive losses to predators, shortage of sheep herders and other labor problems, lack of production/management improvements, competition from alternative enterprises, and employment in other occupations. The objective of this study was to determine which of these and other factors have influenced the decline of the

\footnotetext{
The author conducted this research while as graduate research assistant at Texas A\&M University. Presently, the author is postdoctoral researcher, University of California, Hopland Field Station, 4070 University Road, Hopland, Calif. 95449.

This research was funded in part by the U.S. Fish and Wildlife Service, Denver Wildlife Research Center, Cooperative Agreement No. 14-16-0009-81-934. The author thanks Drs. J.R. Conner, N.J. Silvy, M.J. Shult, and D.A. Wade for their comments on the manuscript, and all the ranchers who so willingly responded to the survey.

Manuscript accepted June 20, 1984.
}

Angora goat industry in 3 Texas counties.

\section{Study Area}

Most of the data for this study were gathered in Bosque, Hamilton, and Coryell counties, Texas. These counties lie within the Grand Prairie ecological area (Gould 1975). The area is dominated by rolling to hilly dissected prairies (Texas State Soil and Water Conservation Board 1981). The original vegetation consisted primarily of tall and mid-grass prairie but stands of honey mesquite (Prosopis glandulosa), juniper (Juniperus spp.), elm (Ulmus spp.), and oak (Quercus spp.) have thickened in many areas (Rechenthin and Smith 1967).

Prairies typically have dark colored clays over limestone (Gould 1975). Average annual rainfall ranges from $76-89 \mathrm{~cm}$ (Texas State Soil and Water Conservation Board 1981). Economically, beef cattle are the most important livestock while oats, grain sorghum, and wheat are the most important crops.

\section{Methods}

During 1981, 104 past producers and 103 present producers in Bosque, Hamilton, and Coryell counties, Texas, were interviewed regarding their goat enterprises. Past and present ranchers were identified by county agents and by other ranchers. An unknown proportion of past producers were contacted; however, based on county livestock statistics (Texas Crop and Livestock Reporting Service $1981 \mathrm{~b}$ ), about $90 \%$ of the goats in these counties were owned by present producers contacted during the study. With 2 exceptions, all ranchers responded to the survey. However, all questions were not answered by ranchers, either because they were not applicable or because ranchers felt they could not provide reliable information. Although most ranchers based their responses on mental recall, some referred to written records, particularly when questioned concerning livestock losses.

Information was obtained on: (1) herd size, (2) ownership of goat enterprises (e.g., single or family partners), (3) rancher characteristics such as age and years in business, (4) management of nannies during kidding, (5) livestock losses due to predators, disease, and other causes, (6) relative use of 7 technqiues to reduce predation problems (i.e., predator control by ranchers, night penning of livestock, confinement or semiconfinement kidding, extra checking on goats, use of guard dogs and the use of scare devices), and (7) the relative importance of various potential production limitations. Ranchers were questioned in 1981. Responses of past producers were based on their last year of production, whereas responses of present producers were based on the 1980 production year.

Chi-square analysis was used to make all statistical comparisons except that a Wilcoxin 2-sample test was used to compare kilometers driven and hours spent by past and present producers using predator control and husbandry techniques.

\section{Results and Discussion}

A total of 104 past producers and 103 present producers was contacted. The distribution of past and present producers among various herd-size classes did not differ statistically $(P>0.05)$; how- 
ever, past producers tended to have smaller operations than present producers. Compared to past producers, $6 \%$ fewer present producers were in the 1-299 class while 6\% more present producers were in the 300-599 class. Relatively few (13\%) present and past producers were in the $\geq 600$ head category of goats. Over $60 \%$ of the present and past producers had $\leq 299$ head of goats. Small operations probably have more alternatives to goat production and more flexibility to make changes than do large operations (Gee et al. 1977). Diversification can reduce risk, permits better use of range, and provides some flexibility to shift to other livestock or crops in response to changes in prices, costs, labor availability, and predation (Gee et al. 1976, Bowns 1980).

Just over $80 \%$ of the operations run by past and present producers had single-owners. There were more family partnerships in the past $(15 \%)$ than at present $(9 \%)$, and more nonfamily partnerships at present $(8 \%)$ than in the past $(5 \%)$; however, none of these differences were statistically significant $(P>0.05)$. Similarly, Stevens and Hartley (1976) found that for the Wyoming sheep industry, $86 \%$ of the sheep operations in their sample were individually owned, while the remaining $14 \%$ were owned primarily by family corporations.

There was no statistically significant $(P>0.05)$ difference between the average number of years present and past producers were in the goat business ( 21.1 and 17.7 years, respectively). Further, the distribution of past and present producers among the various age classes was not statistically different ( $P>0.05$ ), although past producers tended to be older during their last year of production than were present producers in 1980 . Forty-four percent of the past producers were $\geq 60$-years old when they ceased production of goats; $34 \%$ of the present producers were in this category. Further, $7 \%$ of the present producers were $\leq 30$-years of age; none of the past producers were in this category when they ceased production of goats. Overall, there was no significant $(P>0.05)$ difference between the average age of present and past producers ( 54 and 56 , respectively). This 2 -year average difference in age was not as great as the 8 years reported by Gee et al. (1977) for past and present sheep producers in Texas. Gee et al. (1977) also found that few sheep producers in Texas were under age 30 and that relatively few sheep businesses survived the former producers' retirement by being taken over by members of the family or other young persons. As with goat producers in this study, Gee et al. (1977) reported that a relatively high number of producers in their 40's and 50's abandoned sheep production. Stevens and Hartley (1976) reported that the average age of Wyoming sheep producers was 57 .

Ranchers' methods of kidding nannies were categorized as range, shed, and shed/trap kidding. The distribution of past and present producers using these methods of kidding was statistically different $(P<0.05)$. More past producers $(55 \%)$ kidded nannies on range than did present producers $(20 \%)$. Also fewer past producers $(34 \%)$ kidded in shed/trap situations than did present producers $(63 \%)$. The fear of losing kids to predators was the most common reason given for kidding in traps and sheds.

The percentage of kids surviving from a few days old to weaning for past and present producers differed statistically $(P<0.05)$. Seventy-one percent of the present producers reported that their 1980 kid crop was $>50 \%$, whereas only $31 \%$ of the past producers had kid crops in this range during their last year of goat production. Losses to predators reportedly was the main cause of death of kids for both present and past producers. This is supported by Tcxas Crop and Livestock Reporting Service (1983b) data which suggest that in 1982 , predators accounted for $73 \%$ of all goat and kid deaths.

About $50 \%$ of the past producers were unable to provide estimates of the known number of adult goats dying to various causes. The percent of adult goats killed was calculated as: percentage killed = number of goats killed $/$ total number of goats. The total

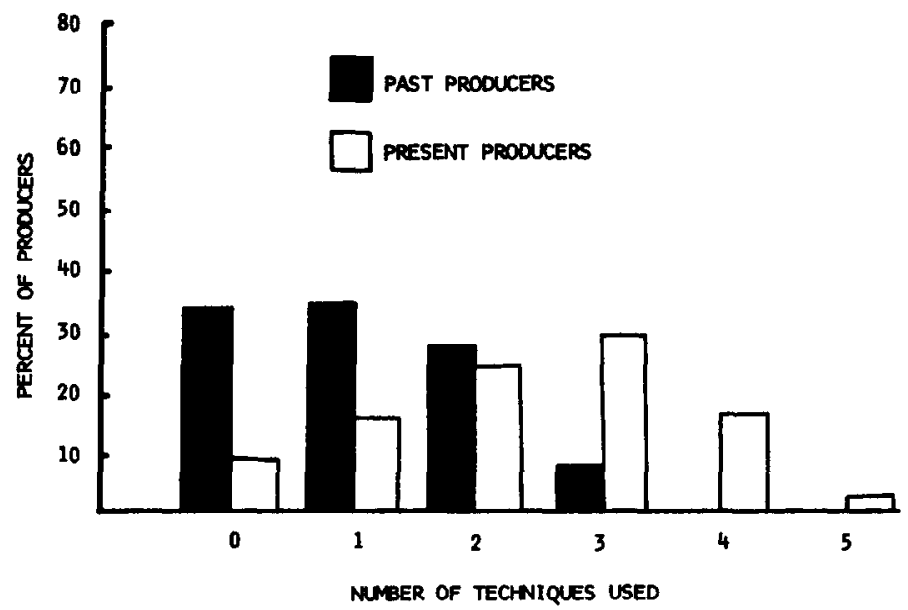

Fig. 1. The number of techniques used by 104 past Angora goat producers and 103 present Angora goat producers to reduce livestock losses to predators. Data were gathered in Bosque, Hamilton, and Coryell counties, Texas.

number of goats was determined by summing the number of goats killed, the number of goats alive at the end of the year, and the number of goats which died to causes other than predation. For past producers, an estimated $16 \%$ of the adult goats were killed by predators during the last production year. Present producers had

Table 1. Mileage and labor for predator control and the percent of ranchers supporting a private or government trapper for 103 present Angora goat producers and 104 past Angora goat producers in Bosque, Hamilton, and Coryell counties, Texas.

\begin{tabular}{|c|c|c|c|c|c|c|c|c|}
\hline & \multicolumn{2}{|c|}{ Bosque } & \multicolumn{2}{|c|}{ Hamilton } & \multicolumn{2}{|c|}{ Coryell } & \multicolumn{2}{|c|}{ Total } \\
\hline & Present & Past & Present & Past & Present & Past & Present & Past \\
\hline \multicolumn{9}{|l|}{ Predator-control mileage } \\
\hline $\begin{array}{l}\mathrm{n} \text { respondents } \\
\% \mathrm{w} / \text { mileage }^{2} \\
\mathrm{~km} / \mathrm{yr}(\bar{x})^{3}\end{array}$ & $\begin{array}{r}21 \\
29 \\
531\end{array}$ & $\begin{array}{r}52 \\
23 \\
341\end{array}$ & $\begin{array}{r}39 \\
36 \\
656\end{array}$ & $\begin{array}{r}20 \\
20 \\
158\end{array}$ & $\begin{array}{r}41 \\
29 \\
356\end{array}$ & $\begin{array}{r}27 \\
22 \\
164\end{array}$ & $\begin{array}{r}101 \\
32 \\
512\end{array}$ & $\begin{array}{r}99 \\
22 \\
256\end{array}$ \\
\hline $\begin{array}{l}\text { Predator-control labor } \\
\text { n respondents } \\
\% \mathrm{w} / \text { labor } \\
\mathrm{hr} / \mathrm{yr}(\bar{x})\end{array}$ & $\begin{array}{l}21 \\
33 \\
59\end{array}$ & $\begin{array}{l}52 \\
27 \\
55\end{array}$ & $\begin{array}{l}39 \\
38 \\
65\end{array}$ & $\begin{array}{l}20 \\
20 \\
21\end{array}$ & $\begin{array}{l}41 \\
29 \\
72\end{array}$ & $\begin{array}{l}27 \\
22 \\
20\end{array}$ & $\begin{array}{r}101 \\
34 \\
66\end{array}$ & $\begin{array}{l}99 \\
24 \\
39\end{array}$ \\
\hline $\begin{array}{l}\text { Trapper-fund support } \\
\text { n respondents } \\
\% \text { contributing }\end{array}$ & $\begin{array}{l}21 \\
52 \\
\end{array}$ & $\begin{array}{l}52 \\
29\end{array}$ & $\begin{array}{l}39 \\
46 \\
\end{array}$ & $\begin{array}{l}38 \\
45\end{array}$ & $\begin{array}{l}41 \\
68\end{array}$ & $\begin{array}{l}28 \\
46\end{array}$ & $\begin{array}{r}101 \\
56\end{array}$ & $\begin{array}{r}100 \\
37\end{array}$ \\
\hline
\end{tabular}

'Not all ranchers responded to all questions, therefore the number of respondents to each question is provided.

'The percent of the respondents who incurred mileage.

${ }^{3}$ The average number of $\mathrm{km} /$ year driven for all respondents. 
Table 2. Penning, kidding, and surveillance mileage and labor used by 103 present angora goat producers and 104 past Angra goat producers for reducing predation losses. Data were gathered in Bosque, Hamilton, and Coryell counties, Texas.

\begin{tabular}{|c|c|c|c|c|c|c|c|c|}
\hline & \multicolumn{2}{|c|}{ Bosque } & \multicolumn{2}{|c|}{ Hamilton } & \multicolumn{2}{|c|}{ Coryell } & \multicolumn{2}{|c|}{ Total } \\
\hline & Present & Past & $\overline{\text { Present }}$ & Past & Present & Past & Present & Past \\
\hline $\begin{array}{l}\text { Penning mileage } \\
\text { n respondents } \\
\% \mathrm{w} / \text { mileage }^{3} \\
\mathrm{~km} / \mathrm{yr}(\vec{x})^{4}\end{array}$ & $\begin{array}{c}21 \\
43 \\
1,368^{* 2}\end{array}$ & $\begin{array}{r}52 \\
12 \\
455\end{array}$ & $\begin{array}{c}39 \\
31^{*} \\
1,091\end{array}$ & $\begin{array}{r}20 \\
5 \\
74\end{array}$ & $\begin{array}{c}41 \\
44 \\
928^{*}\end{array}$ & $\begin{array}{r}27 \\
4 \\
37\end{array}$ & $\begin{array}{c}101 \\
39^{*} \\
1.082^{*}\end{array}$ & $\begin{array}{r}98 \\
8 \\
267\end{array}$ \\
\hline $\begin{array}{l}\text { Penning labor } \\
\text { n respondents } \\
\% \text { w/labor } \\
\text { h/yr }(\bar{x})\end{array}$ & $\begin{array}{c}21 \\
62 \\
177^{*}\end{array}$ & $\begin{array}{l}52 \\
19 \\
77\end{array}$ & $\begin{array}{l}39 \\
54^{*} \\
117^{*}\end{array}$ & $\begin{array}{r}20 \\
5 \\
9\end{array}$ & $\begin{array}{c}41 \\
63^{*} \\
173^{*}\end{array}$ & $\begin{array}{l}27 \\
15 \\
52\end{array}$ & $\begin{array}{c}101 \\
59^{*} \\
152^{*}\end{array}$ & $\begin{array}{l}99 \\
15 \\
56\end{array}$ \\
\hline $\begin{array}{l}\text { Kidding mileage } \\
\mathrm{n} \text { respondents } \\
\% \mathrm{w} / \text { mileage } \\
\mathrm{km} / \mathrm{yr}(\bar{x})\end{array}$ & $\begin{array}{r}20 \\
5 \\
72\end{array}$ & $\begin{array}{r}52 \\
2 \\
3\end{array}$ & $\begin{array}{r}39 \\
5 \\
24\end{array}$ & $\begin{array}{r}20 \\
0 \\
0\end{array}$ & $\begin{array}{l}41 \\
12 \\
34\end{array}$ & $\begin{array}{r}27 \\
7 \\
164\end{array}$ & $\begin{array}{r}100 \\
8 \\
39\end{array}$ & $\begin{array}{r}99 \\
3 \\
47\end{array}$ \\
\hline $\begin{array}{l}\text { Kidding labor } \\
\text { n respondents } \\
\% \text { w/labor } \\
\text { h/yr }(x)\end{array}$ & $\begin{array}{l}20 \\
20 \\
30\end{array}$ & $\begin{array}{r}52 \\
6 \\
5\end{array}$ & $\begin{array}{l}39 \\
26 \\
27\end{array}$ & $\begin{array}{l}20 \\
15 \\
13\end{array}$ & $\begin{array}{l}41 \\
39 * \\
38\end{array}$ & $\begin{array}{l}27 \\
11 \\
18\end{array}$ & $\begin{array}{l}100 \\
30^{*} \\
32\end{array}$ & $\begin{array}{r}99 \\
9 \\
10\end{array}$ \\
\hline $\begin{array}{l}\text { Surveillance mileag } \\
\text { n respondents } \\
\% \mathrm{w} / \text { mileage } \\
\mathrm{km} / \mathrm{yr}(\vec{x})\end{array}$ & $\begin{array}{r}19 \\
5 \\
45\end{array}$ & $\begin{array}{r}52 \\
12 \\
249\end{array}$ & $\begin{array}{c}39 \\
49^{*} \\
788^{*}\end{array}$ & $\begin{array}{l}20 \\
10 \\
21\end{array}$ & $\begin{array}{r}41 \\
29 \\
591\end{array}$ & $\begin{array}{r}27 \\
22 \\
119\end{array}$ & $\begin{array}{c}99 \\
32^{*} \\
563^{*}\end{array}$ & $\begin{array}{r}99 \\
14 \\
167\end{array}$ \\
\hline $\begin{array}{l}\text { Surveillance labor } \\
\text { n respondents } \\
\% \text { w/labor } \\
\text { h/yr }(\bar{x})\end{array}$ & $\begin{array}{l}19 \\
16 \\
28\end{array}$ & $\begin{array}{l}52 \\
19 \\
47\end{array}$ & $\begin{array}{l}39 \\
49^{*} \\
83^{*}\end{array}$ & $\begin{array}{l}20 \\
20 \\
10\end{array}$ & $\begin{array}{l}41 \\
41 \\
52\end{array}$ & $\begin{array}{l}27 \\
30 \\
51\end{array}$ & $\begin{array}{l}99 \\
39 \\
60^{*}\end{array}$ & $\begin{array}{l}99 \\
22 \\
41\end{array}$ \\
\hline
\end{tabular}

Not all ranchers responded to all questions, therefore the number of respondents to each question is provided.

$2 *$ = greater than past producers, $P<0.05$.

${ }^{3}$ The percent of the respondents who incurred mileage.

${ }^{4}$ The average number of $\mathrm{km} / \mathrm{yr}$ driven for all respondents.

$5.1 \%$ of their adults killed during 1980 .

An equation similar to that described above was used to calculate the percentage of kids killed except that no data were available on the number of kids that died to causes other than predation. Thus, the calculated percentage of kids killed is biased slightly high. For present and past producers, 19 and $50 \%$, respectively, of the kids were estimated to have been killed by predators.

of 7 techniques (predator control by ranchers, support of private or government trappers, night penning of livestock, confinement or semiconfinement kidding, extra checking on goats, use of guard dogs, and the use of scare devices) ranchers use to reduce predation losses, present producers used significantly more $(P<0.05)$ techniques than did past producers (Fig. 1). An average of $1.1(\mathrm{SD}=1.0)$ techniques were used by past producers, whereas present producers used an average of $2.4(\mathrm{SD}=1.3)$ techniques.

Also, more present producers (34\%) than past producers $(24 \%)$ used traps, M-44s, snares, and other related predator-control practices (Table 1). Present producers annually travelled an average of $512 \mathrm{~km}$ and spent an average of $66 \mathrm{~h}$ while past producers annually travelled $256 \mathrm{~km}$ and spent $39 \mathrm{~h}$ on these practices. However, these differences were not statistically significant $(P>0.05)$, due primarily to the variability in the data. Furthermore, $37 \%$ of the past producers and $57 \%$ of the present producers supported full or part-time trappers (Table 1). When ranchers paid trapper support, it usually occurred through participation in the cooperative federal-state-county Animal Damage Control (ADC) program. Assessment of rancher fees usually was based on the number of goats owned or the number of acres grazed.

In all counties, significantly more $(P<0.05)$ present producers $(59 \%)$ penned livestock one or more times during the year because of predators than did past producers (15\%) (Table 2). Also, significantly more $(P<0.05)$ kilometers were driven and hours spent by present producers than by past producers for penning livestock.
Whereas present producers annually drove an average of $1,082 \mathrm{~km}$ and spent an average of $152 \mathrm{~h}$ penning livestock, past producers annually drove an average of $267 \mathrm{~km}$ and spent an average of $56 \mathrm{~h}$ penning livestock. Penning required 2 trips/day to pastures where goats were penned: one trip to pen at evening and another to trip to release goats each morning. Thus, when penning was used, travel and labor expenses were significant factors.

Significantly more $(P<0.05)$ present producers $(30 \%)$ spent extra time tending livestock during kidding because of predators than did past producers (9\%) (Table 2). Present and past producers annually drove an average of 39 and $47 \mathrm{~km}$, and annually spent an average of 32 and $10 \mathrm{~h}$, respectively, to tend livestock during kidding (Table 2). Ranchers often indicated that they preferred to kid nannies on the range but, because of predators, kidding took place either in confinement or semiconfinement. Kidding in confinement or semiconfinement may reduce losses due to predators, poor mothering, and unfavorable weather; however, some ranchers preferred to kid on range because of inadequate labor and facilities.

Although more present producers (32\%) reportedly spent extra labor checking livestock because of predators than did past producers (14\%), only in Hamilton County was this difference statistically significant $(P<0.05)$ (Table 2$)$. Often, ranchers indicated that if they had no fear of losing goats to predators they would visit their herds once or twice a week. However, because of predators, present and past producers annually spent an average of 60 and $41 \mathrm{~h}$ extra, respectively, checking on livestock (Table 2). This required present and past producers to travel an average of 563 and $167 \mathrm{~km}$ extra, respectively (Table 2 ).

In this study area, ranchers have only recently begun using livestock guarding dogs. Consequently, no past producers had guard dogs, whereas dogs were owned by 19 present producers. The number of dogs per ranch varied from 1 to 4 . Similarly, no past 
Table 3. Fifteen potential production limitations rated by 103 present and 104 past Angora goat producers 1 in Bosque, Hamilton, and Coryell counties, Texas. Data are listed in percentages.

\begin{tabular}{|c|c|c|c|c|c|c|c|c|}
\hline & \multicolumn{4}{|c|}{ Present producers } & \multicolumn{4}{|c|}{ Past producers } \\
\hline & $\begin{array}{c}\text { Ranked } \\
\text { first }\end{array}$ & $\begin{array}{l}\text { Ranked } \\
\text { second }\end{array}$ & $\begin{array}{c}\text { Ranked } \\
\text { third }\end{array}$ & $\begin{array}{c}\text { Total2 } \\
\text { weighted \% }\end{array}$ & $\begin{array}{c}\text { Ranked } \\
\text { first }\end{array}$ & $\begin{array}{l}\text { Ranked } \\
\text { second }\end{array}$ & $\begin{array}{c}\text { Ranked } \\
\text { third }\end{array}$ & $\begin{array}{c}\text { Total } \\
\text { weighted \% }\end{array}$ \\
\hline Shortage of labor & 1 & 2 & 9 & 3 & 0 & 4 & 5 & 2 \\
\hline Shortage of shearers & 3 & 11 & 6 & 6 & 3 & 11 & 10 & 7 \\
\hline Marketing problems & 1 & 5 & 7 & 4 & 0 & 1 & 5 & 1 \\
\hline Cull goat prices & $\mathbf{0}$ & 2 & 2 & 1 & 0 & 4 & 2 & 2 \\
\hline Mohair prices & $\mathbf{0}$ & 9 & 7 & 4 & 9 & 34 & 18 & 19 \\
\hline Cost of range lease & 0 & 0 & 2 & 0 & 0 & 0 & 0 & 0 \\
\hline Predation losses & 88 & 6 & 0 & 47 & 78 & 11 & 3 & 43 \\
\hline Poisonous plants & 0 & 0 & $\mathbf{0}$ & 0 & 0 & 1 & 2 & 1 \\
\hline Other livestock more profitable & 0 & 0 & 0 & 0 & 0 & $\mathbf{0}$ & 8 & 1 \\
\hline Age of owner & 0 & 2 & 2 & 1 & 0 & 1 & 2 & 1 \\
\hline Inadequate financing & 0 & 0 & 2 & 0 & 0 & 0 & 0 & 0 \\
\hline Adequate income without goats & $\mathbf{0}$ & 0 & 0 & $\mathbf{0}$ & 1 & 0 & 2 & 1 \\
\hline Disease problems & 2 & 28 & 11 & 12 & 2 & 19 & 3 & 7 \\
\hline Competition from synthetics & 1 & 11 & 19 & 7 & 2 & 7 & 20 & 7 \\
\hline Other & 3 & 22 & 33 & 15 & 5 & 8 & 21 & 9 \\
\hline Total & 99 & 98 & 100 & 99 & 100 & 101 & 101 & 101 \\
\hline
\end{tabular}

'Not all producers responded to all questions.

${ }^{2}$ Total weighted $\%=A / B$, where for a given production limitation $A=$ (ranked highest) $(3)+($ ranked second $)(2)+($ ranked third $)$ and $B=$ Sum of $A$ for all factors.

producers reported using scare devices, whereas 3 present producers used propane gas exploders.

Past and present producers were asked to indicate which of 15 factors most influenced their management decisions (Table 3). A weighted percentage was used to summarize the overall importance of each of the factors. Predation was the factor of greatest concern to both present and past producers. This factor alone received a total weighted percent of 47 and 43 , respectively, for present and past producers. Excluding the "other" category, present producers ranked disease problems next (12\%) (caused mainly by large stomach worms Hemonchus contortus), followed by concern for competition from the synthetic fiber industry (7\%). For past producers, concern over the price of mohair received the second-highest weighed rank $(19 \%)$ while shortage of shearers, disease problems, and competition from the synthetic fiber industry tied for third place (7\%).

Applying the weighted percent formula described in Table 3 to data by Nesse et al. (1976), sheep producers in California ranked predator problems first, unpredictable market prices for lamb and wool second, and high property taxes third. For past producers in the western sheep industry, Stevens and Hartley (1976) and Gee et al. (1977) reported predator problems as the primary reason for terminating sheep production, followed by labor problems and poor lamb or wool prices.

In this study, the most common "other" factor mentioned by both past and present producers related to the high cost of fence materials and labor required to keep fences in good condition. Ranchers often indicated that goats, more than any other class of livestock, require well-kept fences; goats are "born looking for a hole in the fence," was a common view expressed by ranchers. Some producers indicated that they knew of pastures in which goats could be placed, but the poor condition of existing fences and the high cost of replacing fences prevented use of these pastures.

\section{Conclusion}

While the distribution of past and present producers among various herd-sizes, ownership, and age classes was similar, it differed with regard to kidding. More present producers attempted to reduce livestock losses by shed and shed/trap kidding and reported higher kid crops than did past producers. Also, present producers reported fewer kids and adults killed by predators and greater use of predator control and husbandry techniques to reduce livestock losses.
When asked to identify the major production limitations, present and past producers both indicated that predation on livestock was the primary problem. This was followed by disease problems and competition from the synthetic fiber industry for present producers, and low mohair prices, shortage of labor, disease problems, and competition from the synthetic fiber industry for past producers.

Based on these data and unsolicited comments by ranchers, it appears that past producers often suffered severe losses to predators at a time when goat and mohair prices were low. Because of low prices, many ranchers could not financially justify adequately protecting goats from predators. This usually led to increased losses.

In addition, many ranchers indicated that as neighboring ranches discontinued goat production, predation intensified on those ranches still raising goats. As a result of increased predation losses, many of these ranches also eventually ceased goat production. Nielsen (1977) also found that in 5 western states, more high-loss ( $8 \%$ or more docked lambs killed by predators) than low-loss ( $0-3 \%$ of docked lambs killed by predators) sheep producers had no other producers within $16 \mathrm{~km}$. Low-loss producers consistently tended to operate in areas of relatively high concentration of sheep. As ranchers ceased goat production, use of predator control practices usually decreased.

Although some past producers indicated they were still making money when they ceased goat production, they had reached a point where they could no longer tolerate the excess losses of their livestock to predators. One rancher indicated that seeing so many goats killed, "affected me mentally .. . I couldn't stand to see what the predator had done. I just had to get out (of the goat business)" (see also F. Howard, 1980). Shelton (1982) pointed out that in addition to the cost in time and money of efforts to prevent predation, the emotional trauma involved is also a major factor in the decline of the sheep industry.

Many past producers indicated that since goat and mohair prices generally have been favorable in recent years, they would like to get back into the goat business. However, due to the risk of severe goat losses to predators and/or the costs associated with predator control and husbandry techniques required to minimize goat losses, they are unwilling to do so.

Clearly, before the number of goats in Texas will significantly increase, ranchers who desire to produce goats must be able to financially justify the efforts required to protect them. This would be possible by increasing gross revenues/goat without increasing 
production costs/goat, or by decreasing production costs/goat without decreasing revenues/goat. The former would be possible if there was a significant increase in goat and mohair prices while the latter would be possible if any one or a combination of production costs were reduced. The development and subsequent use of more effective and less costly methods of predator control and husbandry methods would not only provide the advantage of reducing production costs but also of increasing gross revenues by the marketing of animals which otherwise would be killed by predators.

\section{Literature Cited}

Banks, Q. 1983. Market trends. Sheep! Mar., 1983.p. 16-17.

Bowns, J.E. 1980. Statement for the hearing record. p. 231-234, 503-509. In: Hearings before the Committee on Environment and Public Works, U.S. Senate, Ninety-sixth Congress, Second Session, 24-25 April 1980. Serial No. 96-H52. U.S. Govt. Printing Office.

Cothern, J.E. 1981. Seasonal supply and price trends for lambs in the west. p. 16-45. Proc. Western Lamb Marketing Workshop, 15-17 Sept. 1981. Univ. California Coop. Ext. Serv.

Early, J.O., J.C. Roetheli, and G.R. Brewer. 1974a. An economic study of predation in the Idaho range sheep industry, 1970-71 production cycle. Agr. Exp. Sta., Univ., Idaho, Moscow.

Early, J.O., J.C. Roetheli, and G.R. Brewer. 1974b. An economic study of predation in the Idaho range sheep industry 1972-73. Agr. Exp. Sta., Univ. Idaho, Moscow.

Gee, C.K., and R.S. Magleby. 1976. Characteristics of sheep producers in the western United States. USDA ERS Agr. Econ. Rep. 345.

Gee, C.K., R.S. Magleby, D.B. Nielsen, and D.M. Stevens. 1977. Factors in the decline of the western sheep industry. Nat. Resour. Econ. Div. Econ. Res. Serv., USDA Econ. Rep. No. 377.

Gould, F.W. 1975. Texas plants: a checklist and ecological summary. Texas Agr. Exp. Sta., Texas A\&M Univ., College Station.
Howard, F. 1980. Statement for the hearing record. p. 24-26, 127-139. Hearings before the Committe on Environment and Public Works, U.S. Senate, Ninety-sixth Congress, Second Session, 24-25 April 1980. Serial No. 96-H52. U.S. Govt. Printing Office.

Kensing, R.H. 1978. Economics of Angora goat enterprises. Texas Agr. Exp. Rep., The Texas A\&M Univ., College Station.

Kensing, R.H. 1980. The changing hill county. Texas Sec., Soc. of Range Manage., Annu. Meet., Kerrville, Texas, 5 Dec. 1980.

Nesse, G.E., W.M. Longhurst, and W.E. Howard. 1976. Predation and the sheep industry in California 1972-1974. Div. Agr. Sci. Bull. 1878. Univ. California, Berkeley.

Nielsen, D.B. 1977. High/low predation- some why factors. Utah Sci. 38:82-86.

Rechenthin, C.A., and H.N. Smith. 1967. Grassland restoration: effect on water supply. USDA Soil Conserv. Serv., Temple, Texas.

Shelton, M. 1982. The wild animal damage enigma. p. 28-36. In: J.C. Jones (ed.) A Symposium on Predation. Nat. Animal Damage Control Ass. Albuquerque, N. Mex.

Stevens, D.M., and D.R. Hartley. 1976. Decline in Wyoming sheep industry- a partial explanation. Agr. Exp. Sta., Univ. Wyoming, Laramie.

Texas Crop and Livestock Reporting Service. 1981a. Texas historic livestock statistics: 1967-1981. Texas Dep. Agr. and USDA, Austin.

Texas Crop and Livestock Reporting Service. 1981b. 1980 Texas county statistics. Texas Dep. Agr. and USDA, Austin.

Texas Crop and Livestock Reporting Service. 1983a. 1982 Texas livestock, dairy and poultry statistics. Texas Dep. Agr. and USDA, Austin.

Texas Crop and Livestock Reporting Service. 1983b. Texas agricultural fact. 23 April 1983. Texas Dep. Agr. and USDA, Austin.

Texas State Soil and Water Conservation Board. 1981. Soil and water conservation: the Texas approach. Temple, Texas.

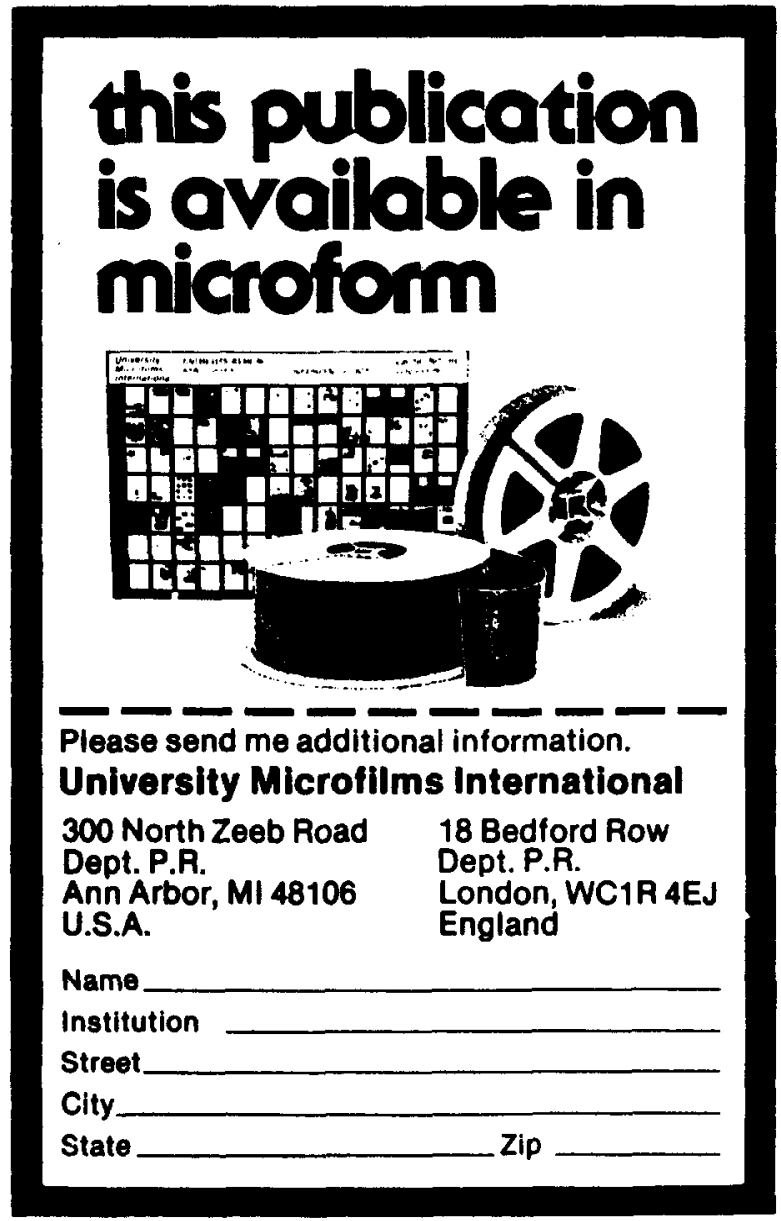

